\title{
A Strategic Analysis of the Delivery of Service in Two Library Reference Departments
} Elsa Sjolander and Richard Sjolander

\begin{abstract}
Two state university library reference departments within the Florida state university system are analyzed, using the framework of a five-task model for strategic management in organizations. The libraries serve different kinds of user populations. One supports a full range of programs through the doctoral level. The other serves only bachelor's and master's level programs. They have similar missions, policies, and scopes of operation. Each department has a clear concept of the implementation of goal-oriented programs. Explicit measurement of service quantity is found in both cases. Service quality is more difficult to measure. No specific measures of service quality were found in either department.
\end{abstract}

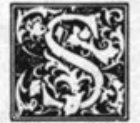

trategy is the managerial game plan for running an organization. It is the design determined before commencing a project that guides the development of the work toward its desired product. In this paper, the framework of strategic management is used to analyze the reference services in two university libraries.

Without an explicit strategy, all but the smallest of organizations would risk encountering either of two sources of operational problems: the ineffective use of resources or the inefficient use of resources. ${ }^{1}$ Each is a serious risk to the organization. Service organizations, particularly not-for-profit service organizations, have been slow to identify potential problems and to adopt the methods of management for the strategic control of their operations. ${ }^{2}$
Strategic management in libraries should meet each of the following five criteria for planning, implementing, and controlling its operations. ${ }^{3}$

- The organization has formulated a philosophy or mission statement for the reference department, which describes its long-range goals;

- The mission is translated into specific, measurable objectives. The objectives or goals for the organization should be stated in terms of desired outcomes;

- A strategy is designed for the achievement of the objectives. It should be the recipe or map that the organization uses to guide its efforts toward the achievement of its stated goals;

- The strategy is implemented efficiently and effectively. To be successfully implemented, the strategy must be communicated to all parts of the

Elsa Sjolander was a librarian at Lund University Library, Lund, Sweden, at the time this paper was written. She is now a librarian in the Escambia County, Florida, School System. Richard Sjolander is Associate Professor in the Department of Marketing University of West Florida, Pensacola, Florida 32514-5752. The authors contributed equally to this paper, and would like to thank the Library and School of Economics and Management at Lund University, Sweden, where much of the work for this paper was conducted. Special thanks to the reference departments at the Pace and Strozier Libraries. The authors would also like to thank the editor and two reviewers for their helpful comments to an earlier version of this paper. 
organization. This will involve the development of tactical plans to guide each function;

The outcomes of the program are evaluated in terms of performance in achieving the specified goals of the organization. Based upon the outcomes, adjustments are made to all parts of the strategic plan, when necessary for future implementation.

The degree to which a strategic framework is used as a guide for library reference department operations is unknown. In this paper, the authors report the results of a strategic analysis of the operations of two academic reference departments.

The process of explicitly determining what the organization's objectives are and then planning a strategy for achieving them appears very simple. Some managers more accustomed to a laissezfaire management style might characterize a strategic framework as rigid or constraining. Such an attitude would be a clear sign that prior planning was not communicated throughout the organization. Effective planning requires that all members of the organization be aware of what is to be accomplished and how it is to be done. Strategic planning has been applied successfully in a wide variety of operations in both for-profit and not-for-profit organizations. ${ }^{4}$

Success is defined in terms of organizational effectiveness and efficiency. In order to be an effective organization, the organization must have goals. Without explicit goals, any level of any service provided to patrons may be judged as satisfactory. ${ }^{5}$ The importance of explicit goals was stated clearly by Theodore Levitt in his classic 1960 article, "Marketing Myopia. ${ }^{16}$ Successful organizations define their businesses in terms of their target customers. Goals must be meaningful to the target customers or clients-in this case the potential patrons of the reference department. A library reference department is effective to the extent that the services it offers are achieving the department's objectives.

By efficiency, we mean that an organization uses the minimum amount of re- sources possible to provide a given quantity and quality of services. ${ }^{7}$ Obviously, any organization, either for-profit or not-for-profit, should strive toward being both efficient and effective. In libraries, questions of efficiency examine whether the same level of library services could be offered using fewer resources. $^{8}$

\section{A library reference department is effective to the extent that the services it offers are achieving the department's objectives.}

The reference departments of university libraries provide an interesting case for applying the framework of strategic management in the analysis of not-forprofit organizations. ${ }^{9}$ Libraries are highly visible service organizations that meet a wide range of publics and serve important functions to overall university operations. The environment of university libraries has changed enormously in recent years. ${ }^{10}$ Henry Mintzberg, in his organizational research studies, found that organizations adapt slowly in response to changes in their environments. ${ }^{11}$ At certain times there will be rapid change, followed by long periods of stagnation and even regression toward strategies which have been discarded as no longer effective. This paper examines the extent to which libraries have adopted new management practices to adapt to the change.

\section{METHOD}

In this study, the reference departments at two American university libraries are compared. These universities are Florida State University (FSU) in Tallahassee and the University of West Florida (UWF) in Pensacola. Several methods of data collection were used. Personal interviews were conducted with the reference department heads. The operations of the two reference departments were observed by the researchers, and the policy documents were analyzed. A questionnaire allowing for structured, 
open-ended responses was constructed and used for the interviews. This facilitated comparison of the departments. A follow-up questionnaire was also sent to each department head for confirmation of certain information.

The comparison centers around the issues of how each library develops and delivers the desired services to its market. The market is defined as the set of actual and potential users of reference services at each library. This study compares the philosophy or mission of the reference department, the reference policy objectives, the types of clientele served, the reference services provided in meeting the objectives, measures of the service quality, the availability of professional librarians, quality and adequacy of the collection, and the evaluation and control of service quality.

\section{DEMOGRAPHICS OF THE MARKETS SERVED}

Libraries at Florida State University (FSU) and the University of West Florida (UWF) were chosen as the libraries for this study. These universities are two of the nine state universities in Florida. Each is located in the main city of a metropolitan area with a population of about 300,000 people and is the major university in its region.

Florida State University (FSU) has an enrollment of slightly more than 28,000 students. The university offers a full range of undergraduate and graduate programs through the doctoral level in the humanities, sciences, engineering, medicine, and law. Florida State began operations in $1857 .{ }^{12}$ FSU is located in Tallahassee, $200 \mathrm{~km}$ from the nearest larger city, Jacksonville, Florida. Tallahassee is the state capital of Florida. More than one hundred state and federal agencies have either head offices or major branches there..$^{13}$ The Strozier Library is the main library at FSU and houses the main reference department. While there are separate libraries for the science and law collections, this study is limited to the reference department at Strozier Library.

The University of West Florida, by contrast, is only twenty-five years old, with an enrollment of almost 8,000 students at the undergraduate and master's levels. No doctoral programs are offered..$^{14}$ The University of West Florida is located in Pensacola, $100 \mathrm{~km}$ from the nearest larger city, Mobile, Alabama. Although Pensacola has a slightly larger metropolitan area than Tallahassee, it has a smaller business center. Pensacola is influenced by the presence of the Navy, other military stations, and beach tourism. The John C. Pace Library houses all collections at the University of West Florida.

The two universities are quite different in terms of location, range and level of programs offered, age of the university, and the number of students enrolled. These differences should be considered when the reference services are compared. Each university supports one branch campus with about 1,500 students.

\section{MISSION STATEMENT}

The philosophies of information service at the two libraries are similar; they are stated in the reference policy statement for each department. The primary purpose of a reference department is to acquire, maintain, and interpret the general reference collection. The librarian on duty is responsible for inquiries-locating the information or instructing patrons in how to find it. ${ }^{15}$ The function of the reference librarian is to help the patrons find what they need, not to conduct the search for them. The authors agree with William Beck and Marsha Nolf that the mission of a reference department determines the choice of objectives, the services provided, and the organization of the services. ${ }^{16}$ The degree of similarity in the missions may be a result of the faculty clients. The faculties of both institutions are involved with research. However, the populations of students served by the two reference departments are quite different. There are no Ph.D. (research) degrees conferred at UWF and the student body comes from a much smaller region; many students combine work and study. The student body at FSU is typical of a large state university. 


\section{REFERENCE POLICY: OBJECTIVES}

Both reference departments have written policy statements. These include general mission statements for the reference departments and their translations into specific objectives for the departments. Both policies follow the "Draft Outline of Reference Service Policy Manual," prepared by the Standards Committee, Reference and Adult Services Division, American Library Association. ${ }^{17}$ These policies state the nature of reference service, types of services offered, main categories of library users, desk service policies and instruction, interlibrary loan service, and bibliographic service. However, UWF's reference policy document is not current. ${ }^{18}$ Most of the reference policies at UWF are incorporated in other policy works such as the collection development and automation policies. The reference department service policy at FSU is current. ${ }^{19}$

The purpose of the reference department in each case is to acquire, maintain, and interpret the general reference collections of the libraries to service the information needs of the patrons. The reference policies can be summarized in the following five points:

- To select, acquire, organize and maintain a reference collection that fulfills the patrons' (students, faculty, staff and community users) need for information;

- To provide information service of high quality to all patrons;

- To provide instruction in the use of the library;

- To cooperate with other library departments, the university community, other libraries, and agencies to provide optimal service;

- To collect statistics for use in evaluation of the reference services.

Both libraries have other policies covering specific areas of their missions. They include collection development, personnel policies describing preferred behavior and methods for achieving contact with patrons, and policies for the management of problem patrons.

These five objectives form the basis for the analysis of the reference depart- ments. The first objective addresses collection development, providing the raw materials necessary to support the reference department's information service function. The next three objectives deal with the provision of reference service to various groups of library users. The last objective, the collection of statistics for use in evaluation, addresses the final step in the strategic management process - the evaluation of outcomes in terms of performance in achieving the specific goals of the organization. Its inclusion as an objective sends up a red flag of caution to the analyst.

There seem to be two possible explanations for the inclusion of this last objective. The organization could consider the measurement and evaluation of its objectives so central to its mission that this is made an objective. The second possibility is that the organization perceives the gathering of statistics on its operations as an end in itself. Libraries have long been enamored with the number of volumes in their collections, for example. While such a statistic may be of importance in evaluating the collection of a national library, it is of dubious worth in the evaluation of a modern university library reference collection. Holdings are of value as they relate to meeting the objectives of the library, not in and of themselves.

\section{Types of Clientele Served}

The study uncovered major differences in the types of patrons served by UWF and FSU. The University of West Florida serves many more patrons who are not associated with the university. Sixty percent of the patrons served at the reference department at UWF are students, faculty, and staff. Forty percent of the patrons are community users. ${ }^{20}$ At FSU, 93 percent are students, faculty, and staff. Only 7 percent are community users. ${ }^{21}$ FSU is located in Tallahassee. This is the state capital with a large public library. Many other information sources and agencies are available to community users. UWF is located in Pensacola, a smaller city with few alternative information sources and agencies. 
Differences in the types of patrons at the two libraries may also result from the strategy chosen by each university to meet its objectives. Here we are referring to how each university and its library perceive their mission. Information to test this hypothesis was not found in the policy statements of the reference departments.

\section{Reference Collection}

Collection development occurs on a continuous basis within the reference department at each library. Reference librarians are responsible for subject area collection development within their areas of expertise. They were found to have specialized knowledge and training in each area of the collection. Clear strategic planning is being followed in the development of the reference collection. Channels of communication with the various academic departments followed subject area responsibility in both departments.

\section{A problem in evaluating the adequacy of the reference collections is that the strategic objective dealing with collection development is not stated in terms of measurable, quantifiable outcomes.}

Both department heads perceived their collections as adequate for the users of the library when the initial survey was completed. UWF has an estimated 30,000 volumes in the reference collection. Strozier's reference collection contains significantly more volumes, which is not surprising because of the greater number of programs, students, and faculty it serves. The Strozier reference department does not have a complete count of its collection. ${ }^{22}$ The quantity of materials in the reference collection is not a measure of the quality of the reference services provided. Resource allocations need to be determined in terms of the objectives to be accomplished.

A problem in evaluating the adequacy of the reference collections is that the strategic objective dealing with collection development is not stated in terms of measurable, quantifiable outcomes. Are the collections current? Do they contain the materials requested/required by the various client groups of faculty, students, and community users? Either regular collection of information from patrons on these issues or periodic patron surveys could be used to gather information on these issues. If the objectives are stated in quantifiable terms, goal achievement can be measured.

\section{REFERENCE SERVICES PROVIDED}

The second objective of the departments is to provide high-quality information services to all patrons. The services described in this section relate to the strategies designed and implemented to achieve this objective.

\section{Desk Service}

Both Florida State University and the University of West Florida libraries provide reference desk services as the nucleus of the information services provided. Inquiries are answered at the reference desk, and some bibliographic instruction is given to patrons who come to the reference department to seek information. Telephone inquiries are also answered at the reference desk.

The location of the reference desk and its design are important factors in the provision of reference services. The reference desk at FSU is highly visible and located on the first floor of the library. The desk is constructed in a semicircle. Located here are two online catalog terminals, an OCLC (Online Computer Library Center) terminal and approximately 10 meters of highly used reference books. The reference desk at UWF is centrally located, but on the second floor of the library. It is not immediately visible to patrons entering the department. The desk equipment consists of two normal height office desks with chairs for the personnel. Chairs are not provided at the desk for patrons, which discourages long conversations at the desk. There are side tables on each side for the online catalog terminals, an 
OCLC terminal, a CD-ROM reader, and approximately 12 meters of shelving for commonly consulted reference sources. It would appear that the location of the reference department at FSU is much better. The contact point for a reference department, usually the reference desk, needs to be highly visible and easy to find.

Beyond the physical location of the reference desks, specific measurement instruments and standards defining levels of acceptable and desired service are necessary to evaluate the quality of the reference desk service in the two departments. Such measures could include friendliness of staff, percent of correct answers given, percent of satisfied users, average time required to answer questions, or waiting time for service. Measures of quality need to be specified in conjunction with the development of the specific objectives of the organization.

\section{Interlibrary Loan}

Both libraries provide the same type of interlibrary loan service. They are part of FLIN (Florida Library Information Network). Most of the interlibrary loans are processed through OCLC. Both libraries have upgraded these services to provide much faster delivery of articles since the survey for this paper was conducted. However, it is not clear how either organization measures its effectiveness in this area.

\section{Bibliographic Service}

All nine universities in the Florida State University system use the LUIS (Library Users Information System) online catalog. Library users can search the entire system's catalog or any individual library collection. The database for educational resources (ERIC), periodical indexes, and other databases can be accessed on the LUIS terminals.

Both university libraries provide information through a variety of online databases. The online services at both libraries are fee-based. The libraries also provide bibliographic services to patrons through the use of CD-ROM-based databases free of charge. The larger Florida state library had a much wider range of databases on CD-ROM than UWF in 1992. The number of CD-ROM-based information retrieval systems has increased tremendously at both libraries since then. Rapid technological advances have reduced the gap between the services available at the two libraries.

\section{Other Reference Services}

Printed guides such as pathfinders, study guides, and subject bibliographies are examples of other services offered at both reference departments. These are seen as aids to the patrons in using the libraries' collections. Subject bibliographies provide an efficient form of information transfer on commonly asked questions. They can also be used as part of a program to standardize the level of service offered to reference desk patrons. Explicit criteria were not found to direct the development of these guides. The effectiveness of the guides was not being measured.

\section{Bibliographic Instruction}

Extensive bibliographic instruction is offered at both reference departments. The programs at the two libraries are similar. They begin with a general introduction and add detail as the user progresses. It should be possible to define the specific goals of these programs and then measure their performance. Surveys could be used to sample both student users and the faculty who grade student assignments based on library research.

\section{COOPERATION AND COMMUNICATION}

Cooperation with other departments of the library and university to provide optimal service was the fourth objective of the reference departments. Few formal strategies were in place to achieve this objective. Both reference departments cooperate with academic departments and research units of the universities concerning the selection of materials. Informal channels also exist for suggestions of acquisitions from patrons. No measures of these efforts are 
being taken. There is no formal communications committee to encourage the improvement of library communication, as suggested by Beck and Nolf. ${ }^{23}$

\section{It is difficult enough to work toward achieving explicit goals; implicit goals often lead to organizational inefficiency and ineffectiveness.}

Patrons are referred to academic departments, other libraries, agencies, and organizations for information that cannot be acquired or received at the reference departments. Counts of the numbers of patrons referred are kept. This measure could be related to the objective.

The issue of internal communication addresses how well the objectives and strategies of the department are communicated to those working in the department. This was not directly measured in the present study. The policy statement in one of the departments had just been revised prior to this study. Communications here would be dependent on the extent to which the members of the department were empowered during the process. The policy statement in the other department was out-of-date. There is a great risk of miscommunication in this case. It is difficult enough to work toward achieving explicit goals; implicit goals often lead to organizational inefficiency and ineffectiveness.

\section{MEASURES OF SERVICE QUALITY}

The final objective of the departments is condensed into a statement about the collection of statistics for use in the evaluation of reference services. The measurement of service quality can be divided into several categories. One common measure of quality in the library literature is the accuracy of information given to specific questions from the patrons. ${ }^{24}$ This has led to the so-called 55 percent rule, meaning that the information given to patrons is accurate 55 percent of the time. ${ }^{25}$ Although the accuracy of the information given to patrons was discussed by both reference depart- ments, neither had implemented a means of controlling this dimension of quality.

As both departments used versions of the same control measures, they will be discussed together. The most common measure of service in each library was actually a measure of service quantity rather than service quality. Both departments kept accurate counts of the numbers of patrons served. These measures were aggregated into two groups: personal walk-ups and telephone inquiries. This is an excellent measure of how many patrons have come in contact with reference librarians. It has no direct connection to either service quality or to the quantity of reference services provided. Customer service questions such as the level of patron satisfaction with the information given and the service provided were not measured.

Accurate counts are kept on the number of patrons receiving the various types of bibliographic instruction. This is seen as the link between the third objective: to provide instruction in the use of the library, and its measure. It is an excellent measure of the number of patrons receiving instruction, but it does not address the quality of the services provided. The UWF reference department staff thought that the broad range of subject bibliographies it developed increased the accuracy and completeness of answers to questions, but this was not measured.

Both libraries track their acquisitions and holdings of reference volumes as a measure of quality. This measure relates to the first objective : the selection, acquisition, organization, and maintenance of the reference collection. The measurement of how well the collection met the patrons' needs for information was informal and was assumed to affect acquisitions to meet future needs. However, this aspect of the objective was not explicitly measured.

The number of interlibrary loans processed was measured. This is another way in which the departments measured the quantity of service provided. Quality measures could be designed around 
various aspects of the service, such as speed of delivery, accuracy of order completion, and degree to which the patron is satisfied with the delivered materials.

From the discussion above it should be clear that departmental objective fiveto collect statistics for use in evaluation of the reference services-is being met in terms of service quantity.

Several areas of service quality are not being measured by either department. First, there are no explicit measures of whether patrons' needs for information are being met. Second, and related to this point, there is no explicit measure of the quality of information service offered to patrons. Each of these points figured prominently into the objectives of the reference departments in relation to satisfying their missions, and is central to an evaluation of service quality. One method to evaluate some of the areas of library service quality is to use focus groups. ${ }^{26}$ Cheryl Elzy and others suggest that a side benefit to measuring service quality may be improvements in the level of service provided. ${ }^{27}$

Personnel development and recruitment is one area of clear strategic planning in each reference department. Each reference librarian has specialized knowledge in one or more of the areas of the collection. Formal subject area knowledge is an important part of each department's recruitment strategy.

An informal measure of service quality in each department was the hours of desk coverage by a professional reference librarian. Both departments stressed that professional reference librarians were on the desk during all hours when there was heavy use of reference servicesdaytime, evening, and weekends. The delivery of services is highly labor-intensive, and this is surely the case for reference information services.

As has been noted in numerous forprofit service organizations, the quality control of employee attitude and performance is roughly equivalent to product quality control in manufacturing industries. ${ }^{28}$ In other words, it cannot be assumed that because a professional librarian is on duty at the reference desk the quality of reference service is high or even adequate. In retail sales, for example, the most common complaint voiced by customers is poor service. Customers do not care if service personnel are "having a bad day." Customers want sales personnel to facilitate their need to have a good day. This point is made quite succinctly by the mail-order firm L. L. Bean

A Customer is not dependent on us ... we are dependent on him. A Customer is not an interruption of our work...he is the purpose of it. We are not doing a favor by serving him ... he is doing us a favor by giving us the opportunity to do so. ${ }^{29}$

Florida State University has about four times the number of students as UWF, but on a per student basis the reference department at UWF has more librarians than FSU. The higher concentration of personnel per potential patron may increase the quality of the service at the smaller school, unless there are significant economies to scale in the delivery of reference services. Both departments related adequacy of staff to the number of hours the library is open, the number of potential patrons it serves, and when those patrons seek help.

\section{DISCUSSION}

The two reference departments studied in this paper are quite different in terms of the size of the student bodies of the institutions and the programs of study offered at them. However, when analyzed from a strategic management frame of reference, they are found to be quite similar. The Strozier reference department has its own policy statement, which was written recently-fall 1991. UWF's library policy statement includes the reference department. This document needs to be updated if it is to serve as a guide for operations. Within the range represented by these two departments - one large research-oriented institution $(28,000$ students) and one medium-sized balanced research/teaching school (8,000 students) - size of the institution does not appear to be a critical factor determining the level of the 
quality of service in many areas of the reference function.

Major differences of the two reference departments compared in this study include the physical location of the reference departments within the libraries and the types of patrons served by the departments. Easy access to the reference department is considered very important. Visibility of the desk is also important. The first-floor location in the Strozier Library is clearly superior to UWF's location on the second floor.

At UWF, 40 percent of the users are community people, and at FSU only 7 percent are. This is probably because of two factors. Access to library borrowing privileges for community members is much less restrictive at UWF. Patrons can acquire library cards at the circulation desk by presenting two pieces of identification. At FSU a letter of request, on business letterhead, is required for all community borrowers. The second factor is proximity to alternate information sources near FSU, which UWF does not have. The public library in Tallahassee is within walking distance of the FSU library.

Both departments are investing for major increases in the level of computer utilization in reference work. The major concern for funding is to expand the reference staff. Apparently, increasing levels of reference automation are not expected to reduce staff. One of the most important measures used by each of the departments to define the quality of a reference service is the number of professional librarians working in the department. Given current trends in reference information service, the number of volumes in a reference department may be less important when evaluating a collection's quality and adequacy in the future. The number of databases available as well as other information retrieval sources will be of increasing importance.

The most surprising finding in this study is the lack of measurement instruments and standards for the evaluation of service quality in library reference departments. The concept of strategic management by objectives has not been totally embraced by these institutions.

\section{CONCLUSIONS}

A strategic management perspective was applied to the operations of two university library reference departments. They were analyzed in terms of the five criteria for planning, implementing, and controlling organizations in this framework. The missions of the reference departments in the two university libraries were found to be quite similar. The objectives developed out of these mission statements were aggregated by the authors into five main areas of emphasis: materials selection, information service, bibliographic instruction, internal and external communication and cooperation, and the collection of statistics for departmental evaluation. These objectives were stated in general terms and not easily translated into measurable objectives.

Each reference department has programs designed to address the five major objectives identified in this study. These programs are being implemented on a continuous basis. Communication of the strategy throughout the organization appears to be implemented more effectively at the larger institution, where the policy statement is up-to-date. The degree to which the entire staff agree with, or even are aware of, the overall department policy was not measured. One way to increase the effectiveness of the communications process within the organization may be through better implementation of the final criterion, the development of a set of outcomes measures to evaluate performance on specific goals.

The outcomes measures used by both departments were found to address various aspects of service quantity. Service quality in most areas was not being measured. There appears to be a lack of congruence between performance measures and stated departmental objectives. The literature on control of library operations indicates that this is not an unusual finding. Service industries have lagged behind goods-producing industries in adopting explicit measures of their productivity. In not-for-profit service in- 
dustries, such as libraries, the adoption has often been further hampered by the unclear statement of objectives. This often leads to a general lack of measurement and evaluation of quality in the delivery of services, a fact that is wellrecognized in the growing literature on services. ${ }^{30}$ Both reference departments in this study have clear objectives. However, in many cases these objectives are not being stated in terms of measurable variables. It is possible to measure the quality of a service just as it is possible to measure the quantity of service provided. Hospitals, restaurants, and hotels provide numerous examples of the definition and measurement of service quality. The library science literature is beginning to recognize that strategic planning can also be implemented in libraries. ${ }^{31}$

Evaluation of the services provided by reference departments was found to be a weak link in the strategic implementation of the programs. While both departments clearly identified quality of service as an objective, neither institution had implemented procedures to measure this important aspect of its mission. This does not mean that libraries must implement procedures to gather large quantities of new data for statisti$\mathrm{cal}$ analysis. There appears to be a need for libraries to be more exact in defining what they propose to accomplish, how to know when they have succeeded, and then to implement control systems simultaneously with their programs. While statistics tell us how many patron questions we have answered, libraries need qualitative evaluation of how well they have met patrons' needs.

Both reference departments recognize that the revolutionary changes going on within library and information science affect the libraries and their users. Not only do these changes in the field of information science lead to changes in the methods and techniques of reference work. They may also alter the relationships of patrons to libraries. The knowledge that large quantities of information exist may make patrons less able to deal with their own ignorance. It has even been suggested that librarians at universities may be seen as symbols of knowledge by some of the faculty. Librarians could, in such instances, be perceived as threats, leading to the need for new service strategies to deal with these situations. ${ }^{32}$ An interesting research topic would be to follow the development of service strategies in reference departments of various types and sizes of universities through the next few years.

The framework of strategic management may be of considerable value in the area of delivering desired reference service at specified quality levels efficiently and effectively in a variety of service industries. The present study has illustrated two such cases.

\section{REFERENCES AND NOTES}

1. Nick Moore, How to Do Research, 2d ed. (London: Library Association Publishing, 1987), $20-45$.

2. James A. Rice, Richard S. Slack, and Pamela A Garside, "Hospitals Can Learn Valuable Marketing Strategies from Hotels," Hospitals 55 (Nov. 1981): 60-73.

3. Arthur A. Thompson, Jr., and A. J.Strickland III. Strategic Management: Concepts and Cases, 5th ed. (Homewood, Ill.: BPI/Irwin, 1990), 3-17.

4. Henry Mintzberg, "Crafting Strategy," Harvard Business Review 65 (July/Aug. 1987): 66-75.

5. Doris J. Schlichter and J. Michael Pemberton, "The Emperor's New Clothes? Problems of the User Survey as a Planning Tool in Academic Libraries," College \& Research Libraries 51 (May 1992): 257-65.

6. Theodore Levitt, "Marketing Myopia," Harvard Business Review 38 (July/Aug. 1960): 45-56.

7. Meredith Butler and Hiram Davis, "Strategic Planning as a Catalyst for Change in the 1990s," College \& Research Libraries 51 (Sept. 1992): 393-403.

8. Moore, How to Do Research, 20-45.

9. Butler and Davis "Strategic Planning," 395-97.

10. Mintzberg, "Crafting Strategy," 72. 
11. Butler and Davis, "Strategic Planning," 398.

12. The Florida State University Bulletin 1993-1994 (Tallahassee, Fla.: Florida State University, 1989).

13. Bureau of Economic and Business Research, College of Business, University of Florida, 1992 Florida Statistical Abstract, ed. Anne H. Shermyen (Gainsville, Fla.: University Pr., 1993), 40-123.

14. The University of West Florida 1993-94 Catalog (Pensacola, Fla.: Univ. of West Florida, 1993).

15. Cheryl Elzy, Alan Nourie, W. Lancaster, and Kurt M. Joseph, "Evaluating Reference Service in a Large Academic Library," College \& Research Libraries 50 (Sept. 1991): 455-65.

16. William L. Beck and Marsha L. Nolf, "The Process and Value of Self-Study in a Medium-sized University Library," College \& Research Libraries 51 (Mar. 1992): 150-62.

17. American Library Association, Standards Committee, Reference and Adult Services Division, Draft Outline of Reference Service Policy Manual (Chicago: ALA, 1984).

18. Peggy Toifel, The University of West Florida Library, Pensacola, Florida, interview, September 1989.

19. "Strozier Library Reference Department Service Policy," Florida State University, 1991.

20. Peggy Toifel, The University of West Florida Library, Pensacola, Florida, interview by mail, January 1992.

21. Greg Toole, Strozier Library, Florida State University, Tallahassee, Florida, interview, September 1989.

22. David Clendinning, Strozier Library, The Florida State University, Tallahassee, Florida, interview by mail, (January 1992).

23. Beck and Nolf, "Process and Value of Self-Study," 153-55.

24. Elzy and others, "Evaluating Reference Service," 458.

25. Robert Burgin, "Reference Accuracy: Improving Our Chances," Wilson Library Bulletin 65 (Nov. 1990): 66-68.

26. Richard Widdows, Tia Aittensler, and Marlya H. Wyncott, "The Focus Group Interview: A Method for Assessing Users' Evaluation of Library Service," College \& Research Libraries 50 (July 1991): 152-359.

27. Elzy and others, "Evaluating Reference Service," 446-64.

28. Rice and others, "Hospitals Can Learn Valuable Marketing Strategies from Hotels," 72.

29. Philip Kotler, Marketing Management (New York: Prentice Hall, 1991), 19, quoting L. L. Bean, Inc., Freeport, Maine, brochure and poster material.

30. Lynn G. Shostack, "Breaking Free from Product Marketing," Journal of Marketing 41 (Apr. 1977): 73-80.

31. Butler and Davis, "Strategic Planning," 393-96.

32. William F. Birdsall, "Why Don't More Faculty Love Librarians?" Journal of Academic Librarianship 18 (Jan. 1992): 375-76.

\begin{tabular}{|cl|}
\hline & \\
\hline & \\
INDEX TO ADVERTISERS \\
COLLEGE \& RESEARCH LIBRARIES \\
ACRL & 90 \\
Biosis & cover 3 \\
Blackwell & 16 \\
Ebsco Subscription & \\
Service & 1 \\
Library Technologies & 32 \\
OCLC & 48 \\
PAIS & 2 \\
Readmore & cover 2, 15 \\
Todd & cover 4 \\
\hline
\end{tabular}

